\title{
Blending Audience Response Systems into an Information Systems Professional Course
}

\author{
Stephen Burgess, Scott Bingley, and David Banks \\ Victoria University, Melbourne, Victoria, Australia
}

\author{
Stephen.Burgess@vu.edu.au; Scott.Bingley@vu.edu.au; \\ traveldab@gmail.com
}

\begin{abstract}
Many higher education institutions are moving towards blended learning environments that seek to move towards a student-centred ethos, where students are stakeholders in the learning process. This often involves multi-modal learner-support technologies capable of operating in a range of time and place settings. This article considers the impact of an Audience Response System (ARS) upon the ongoing development of an Information Systems Professional course at the Masters level in the College of Business at Victoria University in Melbourne, Australia. The course allows students to consider ethical issues faced by an Information Systems Professional. Given the sensitivity of some of the topics explored within this area, an ARS offers an ideal vehicle for allowing students to respond to potentially contentious questions without revealing their identity to the rest of the group.

The paper reports the findings of a pilot scheme designed to explore the efficacy of the technology. Use of a blended learning framework to frame the discussion allowed the authors to consider the readiness of institution, lecturers, and students to use ARS. From a usage viewpoint, multiple choice questions lead to further discussion of student responses related to important issues in the unit. From an impact viewpoint the use of ARS in the class appeared to be successful, but some limitations were reported.
\end{abstract}

Keywords: Blended learning; audience response systems; information systems professionals; ethics

\section{Introduction}

'Traditional' models of teaching and learning in higher education typically comprise a mixture of lectures, used for transmission of facts, out of class activities that involve preparation or assignment work, and seminars that provide face to face interaction with smaller groups. Technology, in the form of presentational systems, recorded lectures and Learning Management Systems, has

Material published as part of this publication, either on-line or in print, is copyrighted by the Informing Science Institute. Permission to make digital or paper copy of part or all of these works for personal or classroom use is granted without fee provided that the copies are not made or distributed for profit or commercial advantage AND that copies 1) bear this notice in full and 2) give the full citation on the first page. It is permissible to abstract these works so long as credit is given. To copy in all other cases or to republish or to post on a server or to redistribute to lists requires specific permission and payment of a fee. Contact Publisher@,InformingScience.org to request redistribution permission. increasingly been used to augment or automate some of these modes of operation (or 'delivery') thus reinforcing the idea of the transmission of knowledge from expert to learner. More recent approaches to course design and implementation acknowledge the role of these technologies but also recognise that there is a need for them to sit sensitively within the broader learning environ- 
ment. One term employed to represent combinations of information and communications technology (ICT)-based and face-to-face learning is blended learning. Bliuc, Goodyear, and Ellis (2007) described blended learning as a mix of different methods, including face-to-face and online teaching, the latter often referred to as 'e-learning' (Wong, Tatnall, \& Burgess, 2014).

Stav, Nielson, Hansen-Nygard, and Thorseth (2010) suggest that 'excellent' teachers arrange their curriculum into an educational system where tasks and assessments are integrated in a suitable learning environment. Learning can clearly take place even in large classes, but to be most effective teachers should be able to adapt their pace, content, or approaches to student levels of understanding on a more immediate or conversational level. As part of a blended learning environment, Audience Response Systems (ARS) can be used to capture and analyse student responses on a real-time basis and can provide a means to capture real-time student responses. A reluctance to engage in question and answer session by raising hands in large groups can be mitigated by the use ARS technology (Swanson \& Piascik, 2014). As well as offering value to large classes, these technologies can also be used in small group settings where they can support discourse around topics that students may find uncomfortable. For example, attitudes and personal actions within ethical situations can be elicited using an ARS and the general group view subsequently presented on screen without any individual being identified.

One of the keys to helping to ensure the successful utilisation of ARS is to take a holistic approach to its implementation. This article outlines the initial stages of a case study of an Australian university that examined the incorporation of ARS into a Masters level unit (course). ARS was predominantly introduced into the unit to encourage students to indicate their own views related to ethical issues encountered by information systems professionals. The results of anonymous 'polls' would hopefully encourage group discussion of the issues that were raised.

As is typical in case studies, multiple approaches were used to source data for the case, including course documentation, a survey of participating students, and the results from the ARS itself. The unique aspect of the implementation is that it follows a blended learning assessment framework to guide the process. The framework suggests that the readiness of stakeholders, the selection of blended learning alternatives, and how the impact of the initiative will be measured should be considered before the introduction of ARS occurs.

This article begins by introducing a blended learning framework and describing how ARS can be considered to be part of a blended learning package. The case study outlining the introduction of ARS into a postgraduate level unit in an Australian university is then presented.

\section{Literature Review}

\section{Blended Learning}

Wong et al. (2014) introduced a 'Blended Learning Assessment' (BLA) framework to consider all aspects of blended learning (see Figure 1).

The BLA framework discusses three aspects that should be considered before a blended learning program is implemented: Readiness of the institution, lecturers, and students to adopt the blended learning program; Intensity of adoption - the selection of blended learning options from those available; and Impact - where the quality and extent of learning are assessed.

The following sections discuss each aspect of the BLA framework.

\section{Readiness}

'Readiness' has previously been used as a term to describe how 'ready' an organisation is to adopt ICT. From an inline viewpoint, Parker (2000) described eReadiness as the level of prepar- 
edness of a business to operate in an eBusiness (or online) marketplace. From a higher education perspective, Machado (2007) developed a framework for assessing eReadiness that differentiates between the roles of university administrators, instructors, and students. This view of readiness was adopted by Wong et al. (2014) in their BLA framework. For blended learning to be adopted effectively, the institution has to have the available technology, lecturers have to be able to use it to design and present curriculum, and students have to be capable of using it. Where these are not currently available, institutions can acquire the technology and lecturers and students can potentially be trained to use it. Easton (2012) notes that institutions and faculty need to be aware of potential accessibility issues relating to ARS and to consider how the use of such technologies relates to accessibility policies within an institution. When examining the introduction of ICT into schools, Binglimas (2009) identified a number of barriers for the institution (schools) and for teachers that related to lack of effective access to the technology, resistance to change, lack of time, lack of training, and lack of technical support. Many of these issues are revisited in the following discussion.

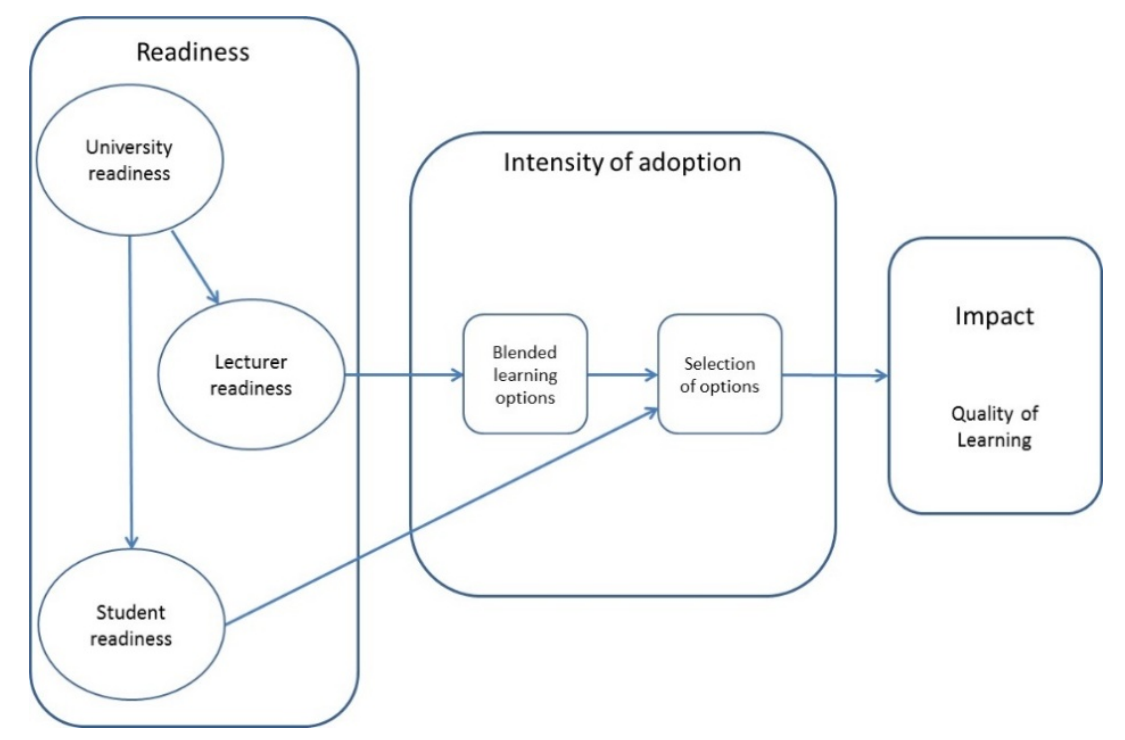

Figure 1: Blended Learning Assessment (BLA) Framework (adapted from Wong et al., 2014)

\section{Intensity of adoption}

Different approaches to teaching could be considered as part of an overall blended learning package (Wong et al., 2014) and can be classified according to a continuum of blended learning that the authors extended from the work of Jones, Chew, Jones and Lau (2009). The continuum stages are:

- Face-to-face (which is delivered with no ICT support);

- Basic ICT use (where ICT is used for simple presentations, such as PowerPoint presentations);

- E-enhanced (where ICT is used for making announcements, storing lecture slides and notes and so forth);

- E-focussed (where ICT is used for online assessment, facilitating discussions and so forth), and

- E-intensive (complete online delivery). 
Shifting from a traditional face-to-face teaching approach to a blended learning environment also requires a shift in delivery from an instructional to a constructivist approach (Bound, 2011). With a constructivist approach, student learning is dependent upon the course material being made meaningful to them according to their own world view. Students need to construct meaning from the program by interpreting the material from their own viewpoint to learn effectively. Biggs and Tang (2011, p. 26) noted:

When students feel this need-to-know, they automatically try to focus on underlying meanings, on main ideas, themes, principles or successful applications...students needing to know will naturally try to learn the details, as well as making sure they understand the big picture. When using the deep approach in handling a task, students have positive feelings: interest, a sense of importance, challenge, exhilaration.

If learning activities can be structured to pose a question or problem and students are motivated to search for solutions themselves and assess the relevance of any information they have found, then learning can occur according to their own world view.

When employing a traditional approach, the teacher plays the role of the 'expert', provides and delivers the curriculum and materials, and makes all of the judgements related to content and assessment. With the constructivist approach there is a change in roles for both parties. The teacher moves from the role of developing and delivering material to one of facilitating student learning, acting as an overall 'manager' of the process. Learners move from being passive listeners to a more active role. They actively search for resources and solutions to problems. Their own experiences and world views are key components of the learning experience (Pittaway \& Thorpe, 2012). This 'active' learning is highly suited to situations where the aim is to apply knowledge gained to a particular context (or applying theory to practice).

\section{Impact}

An approach to assessing the impact of blended learning initiatives should be determined before any initiative commences. Different initiatives can be assessed according to the program content and the approach of instructors.

The method of delivery of a blended learning can be as success factor in its own right. For instance, eLearning can provide advantages over face-to-face delivery in regards to (Elliott \& Clayton, 2007):

- flexibility in time (delivery at a time that best suits learners);

- flexibility of place (different delivery options can provide learners with the ability to learn at different locations, such as remotely), and

- flexibility of delivery (delivery to varied numbers of learners concurrently).

eLearning is particularly suited to people who are time poor and are 'practically minded', selfmotivated learners (Bruce, 2012).

The BLA framework can be applied to an entire blended learning system or when considering an addition to an existing blended learning system (Wong et al., 2014).

\section{Audience Response Systems}

One particular type of blended learning technology is known as audience response systems (ARS). ARS are "easily portable group-support systems that allow participants to use a small hand-held keypad to express their opinions on a range of options that are presented to them on a public screen" (Banks, Monday, Burgess, \& Sellitto, 2010, p. 315). The systems involve a combination of hardware and software and are designed to allow instructors to ask different forms of 
questions to groups of students, allowing them to respond immediately via some type of response device. These systems can break the monotony of lectures in particular and increase teacherstudent interaction (Stav et al., 2010). They are not only suited for large classes, but can also be used in other situations, such as to gauge participant views in focus groups (Banks et al., 2010). Traditionally, the response device was a keypad (or 'clicker') for students to enter their responses and software that can be accessed in real-time by the instructor to create presentations from the results (MacGeorge et al., 2008; Stav et al., 2010). More recently the growth in tablet technologies has led to a proliferation of polling applications of various levels of sophistication. A cursory examination of the Apple App Store reveals over thirty Apps (e.g., PollRunner, CreatePoll, EasyVoting, Vote) that could be included under the heading of Audience Response tools.

There are a number of issues related to the use of ARS that can be addressed from the viewpoint of the BLA framework (readiness; intensity of adoption, and impact). If lecturers or students are not 'ready' to use the technology, then they need to acquire the skills to do so - and have the technology available within the institution. Lecturers can choose the applications of ARS that they wish to use in class (intensity of adoption). The benefits and problems of using ARS can then be assessed (impact) and hopefully the benefits make the effort needed to set up the use of ARS a value proposition.

\section{Readiness}

MacGeorge et al. (2008) suggest that students in disciplines such as science, engineering, or mathematics (who are more comfortable with the use of technology) might be more comfortable using more complex response devices. However, these days many students bring their own mobile devices into classrooms (such as smartphones, tablets, and laptops). These are potential replacements for traditional 'clicker' technology, with a number of online ARS supporting the use of these devices (Stav et al., 2010). The advantage of using these devices is that students are already familiar with them and that the cost burden of specific ARS handsets and associated equipment is removed from students, faculty and institutions (Richards, 2009). Potential disadvantages may occur where there are students without their own mobile devices, if there are problems with network connections, or there is limited access to online ARS via wireless networks. The possibility of technology failure may potentially cause instructor anxiety (Mareno, Bremner, \& Emerson, 2010). Noel, Stover and McNutt (2015) noted an increase in the number of studies that have examined the use of mobile devices for 'polling' in educational settings.

According to Nielsen, Hansen and Stav (2013), it is important that lecturers concentrate upon focussing on how students think and learn when using ARS rather than just relying on the use of the technology to 'improve' lectures. They refer to literature that points out the high levels of ownership of mobile phones amongst students. When combined with the potential use of students' own tablets and laptops, the use of online ARS involving these technologies can be perceived as being more attractive for educational institutions than having to outlay for dedicated ARS clickers.

In regards to the readiness of institutions and lecturers to adopt ARS, for the most part the literature does not discuss the issue from an institutional viewpoint. In some instances, the systems are accessed externally at little or no cost to the institution (such as in Jain \& Farley, 2012) and in others they are incorporated as part of an overall learning management systems. There is an issue of cost related to those institutions having to purchase dedicated response devices, such as clickers (Stav et al., 2010). For the most part, lecturers found ARS relatively easy to use, with the main challenges being the development of suitable questions (Jain \& Farley, 2012). However, it can take some time to learn to use the new technology (Mareno et al., 2010). Nielsen et al. (2013) found that lecturers with prior experience of ARS were rated higher by students. There appeared to be no need for special technical skills or training to be able to use the systems. 


\section{Intensity of adoption}

ARS would be described as being E-focussed on Jones et al.'s (2009) continuum of blended learning, described earlier. ARS might be more attractive as a feedback option for students as their individual responses remain confidential (that is, they do not have to raise their hands in class) (Stav et al., 2010). The use of ARS can improve student engagement and motivation (Mareno et al., 2010). This feature of anonymity offers students the opportunity to express a private view that is not subject to possible peer pressure (Banks, 2003; Draper, Cargill, \& Cutts, 2002; Poulis, Massen, Robens, \& Gilbert, 1998) and may be particularly useful where the cultural norms of some student populations may lead to a reluctance to speak in large groups (Banks \& Monday, 2006). In an examination of the influence of the use of clickers by 198 undergraduate students, Blasco-Arcas, Buil, Hernandez-Ortega, and Sese (2013, p. 108) suggested that "by fostering student communication with their peers and teachers and promoting social and collaborative exchanges among them, clickers help students develop communication abilities and a collaborative spirit." In these social and collaborative exchanges students can discuss the responses with peers and lecturers, leading to exchanges more appropriate to the constructivist approach.

Nielsen et al. (2013) provide a series of recommendations for the effective use of ARS in lectures. Teachers should have a clear goal and motivation for the use of ARS and be consistent in how it is used. Adequate preparation is important to minimise 'dead time' in lectures, which can affect student views of the level of teacher commitment and attitudes towards the use of ARS. Care should be taken in the interpretation of ARS results and subsequent activities. When ARS are used as part of assessment it is important to ensure that students are given the chance to express any uncertainties about the process (Nielsen et al., 2013). Easton (2012) notes that students are cautious about the use of ARS as part of an assessment regime, although they may be willing to accept this if only a small percentage of marks are allocated for responses in lectures.

\section{Impact}

Jain and Farley (2012) suggested that ARS have provided positive and negative results. Positive results include improved classroom participation initiated through instant student feedback and allowing lecturers to tailor delivery based on student responses. However, results are not always positive as there may be resistance to the use of the technology (Jain \& Farley, 2012), or its use may even be a distraction (Jain \& Faley, 2010; Mareno et al., 2010). Effective use needs to be designed around proper explanation of the use of the technology and the design of questions and associated activities that are effective for such systems.

In a study involving the use of VotApedia (an online system that allowed students to record responses to questions through the use of mobile phones), Jain and Farley (2012) interviewed lecturers and ran focus groups with students who used the system. The lecturers generally found the system easy to use, had few problems developing questions, and found that the system's output influenced teaching (such as providing further explanation for concepts that were not understood). The students enjoyed the interactivity and understood that the results enabled lecturers to tailor their programs to them. An important outcome was that both local and international students were able to interact without 'losing face' (something that might occur by having to raise hands in a lecture room). The students did point out problems with using the technology as an issue, such as when the VotApedia system was overloaded or when lecturers did not provide sufficient time to submit their responses and review results. Another potential problem was that overuse of the ARS might be a distraction (Jain \& Farley, 2012). In a literature review, Nielsen et al. (2013) identified a number of other potential problems, including too much time being spent on ARS (in setting it up and/ or discussing results), its use for grading purposes, relying on it to improve attendance, poorly designed questions, poor follow-up of results, and/or ARS being used just for the sake of it. 
Noel et al. (2015) found that students who used their own mobile devices to respond to online ARS provide similar positive feedback to that found in previous ARS studies.

MacGeorge et al. (2008) suggested that earlier ARS studies only evaluated their use on a limited set of criteria (such as student engagement) and less on other aspects, such as actual learning or effectiveness. The authors developed a 'multi-dimensional' approach to evaluating the performance of audience response systems, incorporating the following aspects, some of which have already been mentioned:

- Exam preview: knowing what to expect on examinations, quizzes or assignments

- Self-appraisal: self-assessment of performance in class

- Learning: overall understanding of material

- Negative grade: whether the technology is interfering with learning

- Attendance: likelihood of attendance due to the use of ARS

- Fun: when using ARS

- Liking: level of enjoyment when using ARS

- Future use: propensity to use ARS in the future

- Preparation: influence of ARS on likelihood of preparing in advance for class Motivation: influence of ARS on enthusiasm to learn

- Ease of use: of ARS

- Participation: influence of ARS on sense of participation

- Class time: suitability of time spent using ARS

- Privacy: concerns about other students seeing ARS responses

- Attention: influence of ARS on level of attentiveness in class.

Another limitation of previous ARS studies is a reliance on 'one-time' evaluations, where the novelty factor of using the technology might affect results (MacGeorge et al., 2008).

\section{Summary}

This article has thus far introduced blended learning and audience response systems as a particular aspect of blended learning that can be considered by instructors. ARS provide a number of advantages that lead towards the types of interactions desired in the constructivist approach to curriculum delivery. However, the use of ARS requires careful consideration. Adopting a framework such as the BLA assessment framework in advance of adopting ARS can potentially assist instructors to adopt ARS for the right reason and to avoid the pitfalls that might occur through inadequate planning of its use.

The following sections outline the initial stages of a multi-semester case study designed to incorporate ARS into a Masters level course in an Australian university. The unique aspect of the implementation is that it follows Wong et al.'s (2014) BLA framework to guide the process.

\section{Methodology}

\section{Case Study/ Pilot Study}

Victoria University, located in Melbourne, Australia, has been operating as a university since the early 1990s. Its College of Business offers a number of Masters programs, two of which are the Master of Business (Enterprise Resource Planning systems) and the newly introduced Master of Business Analytics. These courses are designed to prepare students for future roles as information systems (IS) professionals. A core unit (course) in each of these programs is BCO6672, The Information Systems Professional. This unit is offered in campuses of the university in Australia, but also with partner education institutions offering Victoria University courses overseas. 
This article reports on a case study involving the delivery of BCO6672 in the university's primary campus in Melbourne. As per Yin (2003), the unit of analysis of the case study is the delivery of the unit in a particular semester - in this instance Semester Two, 2015 (which ran between JulyOctober 2015). As is typical in case studies, multiple approaches are used to source data for the case (Yin, 2003). These include an examination of course documentation to ascertain the aims of the unit, a survey of participating students, and the results from the ARS itself. Quantitative results are analysed using base statistics as described later. Qualitative answers from the survey are grouped according to themes identified within specific questions.

Future research will examine further instances of delivery of the unit.

\section{BC06672: The Information Systems Professional}

This section provides an outline of BCO6672. The unit aims to provide students with an overview of the requirements and skills for responsible and ethical membership in the information systems profession, as well as opportunities to develop and apply information systems, communications and management skills and competencies within a variety of professional practice scenarios. The aims of the unit include that students:

- be aware of the ethical issues facing IS Professionals.

- be able to present and write authoritatively about the ethical issues facing IS Professionals.

- participate in debates and see both sides of the argument regarding ethical issues facing IS Professionals.

During the semester, students are expected to participate in discussions in lectures and tutorials and are assessed according to their level of participation.

The existing unit is delivered with the assistance of the learning management system, Desire2Learn. This product has been configured for use by Victoria University and rebranded within the university as VUCollaborate. In BCO6672 the system is used to store unit outlines, lecture slides, tutorial exercises and solutions, links to online resources, and so forth. The system allows students to submit assignments electronically and incorporates plagiarism detection software as part of that submission system. Whilst the system provides excellent support for the traditional instructional approach (as per Bound, 2011), it does not easily provide the tools necessary to support constructivist learning. Academic staff within the university are required to use VUCollaborate in the delivery of each unit - but the specifics of how it is used are left to individual staff members.

The unit was first delivered by two of the authors in Semester One, 2015. It had been 'inherited' from other lecturers who had delivered it previously. In that first semester, lectures were delivered using a traditional, structured approach. Two of the authors had also had previous experience using ARS and the nature of the material seemed to make it ideal for a change in approach of delivery towards a more constructivist approach.

The particular aims for use of the ARS were:

- To 'automatically' identify students who participated in ARS polling in lectures to record their participation (as part of their assessment). We understood from the literature the potential hazards of doing this. However, attendance levels in lectures in units were poor across the entire programs and we were looking for a way to reverse this.

- To allow students to provide their views anonymously. This was important as we raising ethical issues. It was also a challenge given the first aim! 
- To allow students to use a standard, mobile device to enter their responses (laptop; tablet, smartphone). This meant that students were familiar with the technology, and also that the university did not have to outlay for dedicated response devices.

- To allow student views to be recorded if the technology failed (if they did not have a mobile device with them or if they could not connect to the wireless network for some reason).

- Allow for real-time summaries of results for class discussion.

Blended learning approaches can be of use when introducing students to approaches that they can employ to deal with ethical issues that they may face in the workplace (Fong, 2015). Initially, students may be wary to discuss such situations with each other, especially in face to face discussions. An ARS is useful for such situations, but as Fong (2015) outlines, can really effectively be used only for closed-ended questions with either a limited list of answer choices or very brief responses. However, Fong points out that the output from these systems can feed into subsequent face-to-face discussion or more involved class participation.

\section{An audience response system initiative}

The decision was made to trial an online ARS known as Socrative, designed by MasteryConnect (www.Socrative.com). This system is "... an easy-to-use tool for building assessments and seeing results in real-time" (Socrative user guide). Further, "Socrative empowers you to engage and assess your students as learning happens. Through the use of real-time questioning, result aggregation, and visualization, you have instant insight into levels of understanding so you can use class time to better collaborate and grow as a community of learners" (www.Socrative.com, accessed 8 November 2015).

The idea was to cautiously introduce Socrative into the lecture material (and into some tutorials) throughout the semester. When issues arose that would benefit from a student poll, Socrative was used to pose a question to students. After their responses were entered they were asked to discuss the results between themselves for a few minutes and then a general discussion occurred - much as in the manner described in the literature review.

Whilst the aim was to introduce ARS into the unit to a greater degree with a shift towards a more constructivist approach, this more cautious approach was seen as being a suitable approach to take in the first instance. Another advantage was that due to expected increased enrolments (due to the introduction of the Master of Business Analytics), the unit was being offered in Semester Two for the first time. Whilst the unit had previous typically had 50-70 students enrolled, this 'transition' semester only had 12 students enrolled.

The next section provides an example of a typical ARS exercise from one of the lectures.

\section{Example of Use of Socrative}

During the semester students are introduced to the concept of 'professionals' and 'professional associations'. The dual role of professional associations is to protect the interests of professionals and the public interest (Chartered Quality Institute, 2015).

In lectures, students are presented with the following ethical situation (given to them in a handout and presented on a slide):

You work as an application developer for a small contracting business, OPS. Your speciality is in designing applications that interface with accounting software, specifically spreadsheet and small database applications.

You have been assigned the task of developing a forecasting spreadsheet application for a new client, ABCD, a small business that has just set up a brand new peer-to-peer network of PCs, 
each installed with new accounting software. This represents $A B C D$ 's first move into computerisation.

Upon talking to the owner/manager of $A B C D$ about the requirements of the spreadsheet you are developing, you by chance ask them where they purchased their computers and network. The owner/manager of $A B C D$ replies that they got a "really good deal" and that "one quote stood out from the rest". The PCs and network were installed by CSP, a business you are familiar with.

After further examination, you determine that one of the reasons for the low quote was that CSP provided the PCs and network at normal rates, and "threw in" the software at no extra cost. You determine that there are unlicensed copies of the accounting software on each of ABDC's PCs.

What do you do?

Students are first of all asked a question about $\mathrm{ABCD}$ : After reading the case study, what do you do about ABCD?

Refer to Figure 2 an example screen of how Socrative presents the results. Results were mostly evenly split between informing ABDC about their licencing responsibilities but still designing the spreadsheet (43\%) and refusing to design the spreadsheet until legal licenses for the accounting software had been obtained.

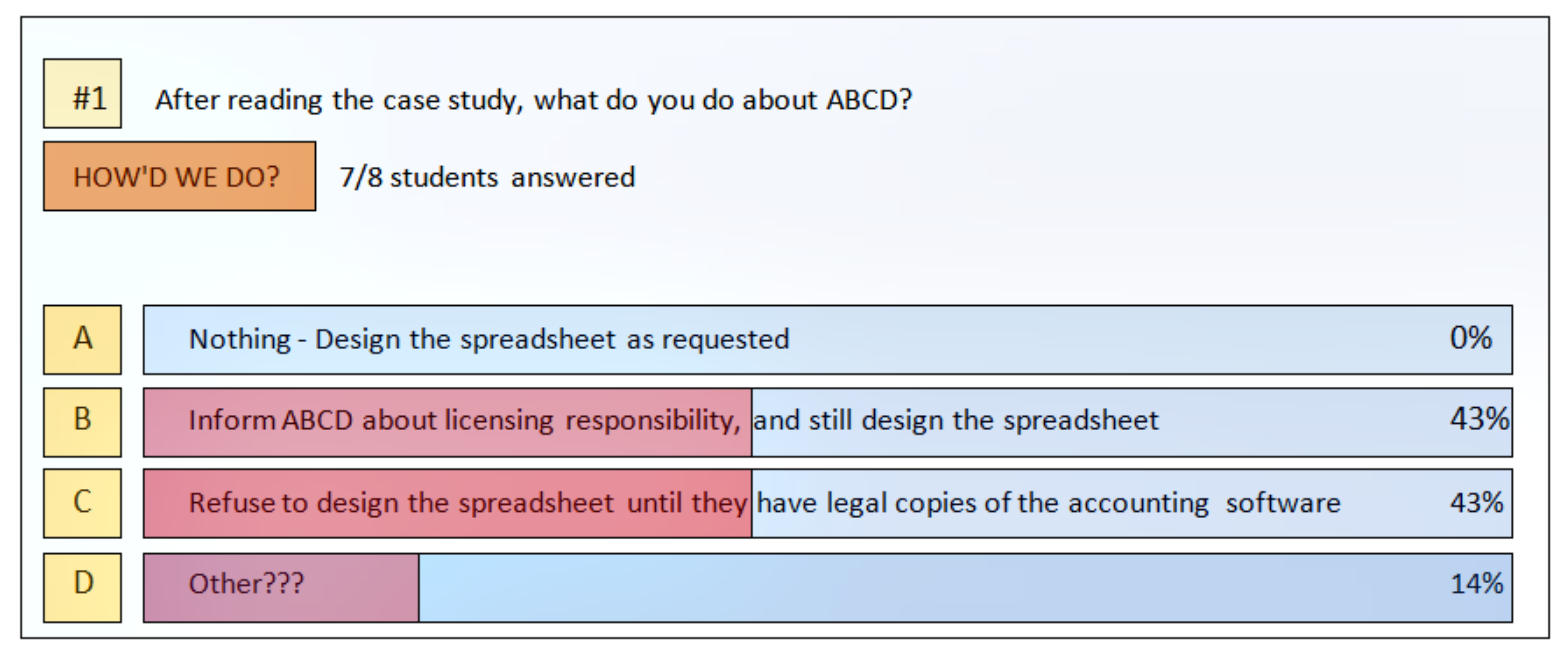

Figure 2: Results for first Socrative poll question

However, the results became really interesting when students were asked three questions about CSP. In the first instance, they are asked to indicate what they would do about CSP after reading the case study. Refer to Table 1 for these responses. Most of the students (71\%) suggest that they would ring CSP and give them a chance to provide licensed copies of the software to ABDC.

However, the students are then asked what they would do if CSP were direct competitors to their own business. The responses then switch to being somewhat tougher $-43 \%$ of the students were prepared to report CSP to legal authorities. Finally, the students are asked what they would do if the CSP consultant was a family member. Again, there is a shift in the results, with no students indicating that they would report them to legal authorities and $29 \%$ of students indicating that they would ring them directly.

In the subsequent discussion, students are asked to consider if, as professionals, their answers should be different for any of those questions. More importantly, they are then introduced to the notion of a Code of Ethics (as per Babu, 2007): 
- A set of rules that governs the behaviour of the members of an organisation that has set up the code.

- Professional behaviours and values that professionals must know and abide by.

- An organised group of ethical behaviour guidelines which govern the day-to-day activities of a profession.

Table 1: Socrative responses about CSP

\begin{tabular}{|c|c|c|c|}
\hline ARS Response & $\begin{array}{l}\text { Question } 1 . \\
\text { After reading the } \\
\text { case study, what do } \\
\text { you do about CSP? } \\
(\%)\end{array}$ & $\begin{array}{l}\text { Question } 2 . \\
\text { But, what if your } \\
\text { business (OPS) also } \\
\text { provides accounting } \\
\text { software and CSP } \\
\text { are a direct competi- } \\
\text { tor? }(\%)\end{array}$ & $\begin{array}{l}\text { Question } 3 . \\
\text { But, what if the CSP } \\
\text { consultant who dealt } \\
\text { with ABDC is a close } \\
\text { family member } \\
\text { (brother/ sister)? } \\
(\%)\end{array}$ \\
\hline Nothing & 14 & 0 & 14 \\
\hline $\begin{array}{l}\text { Ring them and tell } \\
\text { them what you think } \\
\text { of them }\end{array}$ & 0 & 0 & 29 \\
\hline $\begin{array}{l}\text { Ring them and give } \\
\text { them a chance to 'fix' } \\
\text { it by providing li- } \\
\text { censed copies }\end{array}$ & 71 & 43 & 57 \\
\hline $\begin{array}{l}\text { Report them to an } \\
\text { association like the } \\
\text { ACS }\end{array}$ & 0 & 14 & 0 \\
\hline $\begin{array}{l}\text { Report them to the } \\
\text { legal authorities }\end{array}$ & 14 & 43 & 0 \\
\hline
\end{tabular}

A professional organisation's standards for entry should include a requirement to adhere to an enforceable Code of Ethics, the requirement to commit to measurable ongoing professional development and sanctions for conduct that falls below the required standards. A code of ethics has two aspects (Professions Australia, 2015):

- The content comprising the requirements, the rules, principles, ideals, and so forth.

- The commitment of the members of the occupation or organisation to conform to, and otherwise uphold, these rules and ideals.

The students are then shown the Code of Ethics for the Australian Computer Society, which is discussed. They are then asked to reconsider their responses on the basis that they now have a Code of Ethics to guide their behaviour.

\section{Results and Discussion}

This section discusses the setup and initial evaluation of the use of ARS in BCO6672, using Wong et al.'s (2014) BLA framework as a lens of analysis. 


\section{Readiness}

The BLA framework suggests that the readiness of the institution, lecturers, and students needs to be considered for implementation of a blended learning initiative. In this instance, the online ARS required the existence of projection screens with access to a web browser in the lecture and tutorial rooms and a wireless network for students to be able to access the system. These were in place.

Lecturers had to be able to use the online ARS. The lecturers found the system to be relatively easy to use, similar to other ARS as reported in the literature (see Jain \& Farley, 2012). Being lecturers in an information systems department, it is reasonable to assume that they should have been able to master the technology fairly easily.

It was expected that most students would possess the mobile devices necessary to access the system - and this was indeed the case. All of the students accessed the system either by smartphone, tablet, or laptop throughout the semester. The students were requested by Socrative to enter their name (see later) and then were presented with one of more questions to answer. As they entered their results the main screen showed (real-time) how far they had progressed. For instance, if they had answered one of two questions then the system would show that they had completed $50 \%$ of the exercise.

On rare occasions some students had difficulty connecting to the system. For these instances, Socrative provides an option to print out the questions, with each of the questions numbered and the options available with check marks next to them. Students were able to fill these out and hand them to the lecturer. Where only one student had difficulties it was possible for the lecturer to enter the response whilst other students were entering their responses. This would not be practical in a larger class - but hopefully the small proportion of students who were affected would not influence the overall result.

To overcome the problem of being able to track which students participated, but at the same time maintain anonymity, students were requested to enter their student number instead of their name in the 'name' field of the online form they filled in on Socrative. This allowed the lecturer to identify that they had participated after the lecturer, but did not reveal their identity to other students.

\section{Intensity of Adoption}

As mentioned earlier, delivery in BCO6672 has substantially involved what Bound (2011) described as the instructional approach. The aim of this initial use of ARS was to use multiple choice questions to generate subsequent discussion (as described by Fong, 2015). As already demonstrated, Socrative is very suited to this approach.

Socrative also allows for:

- 'Quick questions' - where a lecturer can set up an impromptu question.

- Multiple choice questions with 'correct' answers to allow for graded assessment. With this option the lecturer can also add text to explain why a particular response is correct or incorrect, which is returned to the devices of individual students based upon their response. The lecture can also set up true/ false questions in the same manner.

- Short answer questions - where students can submit brief text responses. This is obviously for later analysis or grading by lecturers as assessment of these cannot occur in real-time.

- 'Space race' - where students compete against each other to be the first to achieve a certain number of correct answers. Their progress against other students is represented on the presentation screen as a series of rockets moving from one side of the screen to the other, with each student being represented by one rocket. 
- 'Exit ticket' - students have to answer a predetermined number of questions. The lecturer is notified once the questions are completed by the student.

Reports can be generated from the system in either PDF or Excel format after the event. In BCO6672 these are only used to record participation in polls and thus no detailed analysis is required.

\section{Impact}

In assessing the impact of the ARS, it was decided that MacGeorge et al.'s (2008) set of questions across 15 different evaluation dimensions would provide the most comprehensive coverage. However, their list of questions totalled 45, which was regarded as being too unwieldy for this assessment. As such, the number of questions were reduced to 26 (plus three open-ended questions) and rewritten for the use of the ARS in its local context, with questions viewed as being repeated also being removed. This process is described in the Appendix to this article.

Where possible the results are compared against other studies. For instance, Noel et al. (2015) conducted a study of 95 undergraduate students using mobile devices to provide responses to an online ARS. They used a scale of four potential responses ranging from ' 1 ' (strongly agree) to ' 4 ' (strongly disagree). In order to report on this, the closest response will be provided (e.g., a mean of 1.2 would mean 'strongly agree'; 1.5 would mean a response between 'agree and strongly agree'). Other ARS studies that are referred to are Stav et al. (2010) and Jain and Farley (2012).

It should be noted that whilst the class has 12 enrolments, only seven completed the survey. The assessment was conducted (using Socrative) in the last week of class. Two of the students were absent and three were held up in other classes. It was necessary to conduct the survey early in the lecture as a guest speaker was invited to speak later in the class. Whilst it was felt that $58 \%$ of the class would give us an idea of the views of the students participating in that semester, we obviously would not consider trying to generalise the results outside of the class. Basic statistics (mean and proportion of agreement with statements) have been used to summarise the results. This allows for some basic comparison with other, similar, studies. However, the results have provided some guidance as to whether we should proceed with the use of ARS and allowed us to trial the evaluation for use in class in the following semester, when numbers will be greater.

Table 2: Responses to learning questions

\begin{tabular}{|l|c|c|}
\hline Learning & Mean & $\begin{array}{c}\text { \% agree or } \\
\text { strongly agree }\end{array}$ \\
\hline My knowledge of course material is improved by using Socrative & 4.14 & 100 \\
\hline I understood more in this class because we used Socrative & 4.00 & 71 \\
\hline Socrative helped me to learn the course material better & 3.71 & 86 \\
\hline
\end{tabular}

For the most part students felt that Socrative assisted with their learning, with the mean responses average around the 'agree' response and most students in agreement with the statements (refer to Table 2). This is consistent with other studies. Stav at al. (2010) asked to what extent the ARS aided students learning of the course curriculum and $74 \%$ indicated that it did to a 'large' or 'very large'. Jain and Farley (2012) asked whether ARS helped students to learn the material and 65\% agreed or strongly agreed that it did. Noel et al. (2015) asked whether using real-time polling during class helped students to better understand the class material. The mean result suggested that responses were closest to 'agree'. 
Table 3: Responses to attendance questions

\begin{tabular}{|l|c|c|}
\hline Attendance & Mean & $\begin{array}{c}\text { \% agree or } \\
\text { strongly agree }\end{array}$ \\
\hline $\begin{array}{l}\text { Because Socrative was used, I attended class more regularly than I } \\
\text { would have otherwise }\end{array}$ & 3.57 & 57 \\
\hline Socrative motivated me to attend class & 3.43 & 57 \\
\hline
\end{tabular}

Jain and Farley (2012) asked whether the use of ARS provided additional motivation to attend classes. Only $41 \%$ of students agreed or strongly agreed that this was the case. In our study (refer Table 3), just over half of the students indicated that it had an effect on their attendance. This could be because the students understood that marks were allocated for participation in Socrative discussions, although this would need to be confirmed with a larger group in later semesters.

Table 4: Response to 'fun' question

\begin{tabular}{|l|c|c|}
\hline Fun & Mean & $\begin{array}{c}\text { \% agree or } \\
\text { strongly agree }\end{array}$ \\
\hline Using Socrative was fun & 3.71 & 86 \\
\hline It was exciting to answer questions using Socrative & 4.00 & 86 \\
\hline
\end{tabular}

The use of ARS was viewed as being fun for students in other studies. When Stav et al. (2010) asked if it was fun to be at lectures where ARS was used, 75\% agreed that it was. Noel et al. (2015) asked if using mobile devices for real-time polling during class was fun. The mean result suggested that responses were between 'agree' and 'strongly agree'. The mean results in our study are also group around 'agree'. However, one student in particular had difficulty connecting to the system throughout the semester. This student's thoughts are reflected in later results.

Table 5: Responses to 'Like' questions

\begin{tabular}{|l|c|c|}
\hline Liking & Mean & $\begin{array}{c}\text { \% agree or } \\
\text { strongly agree }\end{array}$ \\
\hline I enjoyed using Socrative & 3.86 & 86 \\
\hline
\end{tabular}

Noel at al. (2015) asked students if they liked using a personal mobile device to engage in realtime polling during class. The mean result suggested that responses were closest to 'strongly agree'. The results of our study were similar (refer to Table 5), with the one student mentioned earlier indicating ambivalence to the question ('neither agree nor disagree').

Table 6: Responses to future use questions

\begin{tabular}{|l|c|c|}
\hline Future use & Mean & $\begin{array}{c}\text { \% agree or } \\
\text { strongly agree }\end{array}$ \\
\hline I think that Socrative should be used in this class in future semesters & 4.14 & 86 \\
\hline
\end{tabular}

When Stav et al. (2010) asked if ARS should be used in all classes/ lectures, $78 \%$ of students indicated that they 'agreed' or 'strongly agreed'. The MacGeorge et al. (2008) question that we asked (refer to Table 6) was slightly different in that it asked whether the ARS should be used in future delivery of the same unit. Again, all but the single student mentioned previously mentioned that it should be. 
Table 7: Responses to 'preparation' questions

\begin{tabular}{|l|c|c|}
\hline Preparation & Mean & $\begin{array}{c}\text { \% agree or } \\
\text { strongly agree }\end{array}$ \\
\hline Using Socrative encouraged me to do readings prior to class & 3.29 & 43 \\
\hline $\begin{array}{l}\text { Because we used Socrative I prepared for class more than I would } \\
\text { otherwise }\end{array}$ & 3.29 & 29 \\
\hline
\end{tabular}

Table 7 shows the results of the questions that relate the use of Socrative to encourage students to prepare in advance for the class. The low result is not unexpected as this was not an aim of the use of Socrative. However, as we think about moving from an instructional to a constructivist approach to delivery this is something that we seriously consider.

Table 8: Responses to motivation questions

\begin{tabular}{|l|c|c|}
\hline Motivation & Mean & $\begin{array}{c}\text { \% agree or } \\
\text { strongly agree }\end{array}$ \\
\hline $\begin{array}{l}\text { Socrative boosted my enthusiasm for studying the material we } \\
\text { learned in this course }\end{array}$ & 3.71 & 71 \\
\hline Using Socrative made me more motivated to learn in this course & 3.71 & 71 \\
\hline $\begin{array}{l}\text { If we didn't use Socrative, I would be less interested in the topics } \\
\text { we covered in this course }\end{array}$ & 2.71 & 14 \\
\hline
\end{tabular}

Table 8 shows the results of questions related to the effect of the use of Socrative on student motivation. Whilst the general, positive effect of Socrative is consistent with the early results, the results of the question regarding what would happen if Socrative was not used are quite interesting. They suggest that the students would still be interested in the course material whether Socrative was used or not. It will be interesting to see if this result is reflected with a larger sample.

Table 9: Responses to ease of use questions

\begin{tabular}{|l|c|c|}
\hline Ease of use & Mean & $\begin{array}{c}\text { \% agree or } \\
\text { strongly agree }\end{array}$ \\
\hline Using Socrative was easy & 4.14 & 86 \\
\hline I had no problems using Socrative & 4.00 & 86 \\
\hline
\end{tabular}

When Jain and Farley (2012) asked if ARS was easy to use, 69\% of their students agreed or strongly agreed that it was. In our study (refer to Table 9), all but the one student already mentioned indicated that the ARS was easy to use. Again, this was not an unexpected result.

Table 10: Responses to participation questions

\begin{tabular}{|l|c|c|}
\hline Participation & Mean & $\begin{array}{c}\text { \% agree or } \\
\text { strongly agree }\end{array}$ \\
\hline I felt more engaged during class because we used Socrative & 3.57 & 71 \\
\hline $\begin{array}{l}\text { Using Socrative heightened my interest in whatever else we did dur- } \\
\text { ing class }\end{array}$ & 3.43 & 43 \\
\hline
\end{tabular}

Stav et al. (2010) asked to what extent the use of ARS encouraged and motivated their students. $74 \%$ indicated that it did, to a 'large' or 'very large' extent. Noel et al. (2015) asked students if 
they felt more connected to the class when participating with real-time polling. The mean result suggested that responses were closest to 'agree'. The results in our study (Table 10) suggest that the results were not strong in regards to the flow-on influence that Socrative had on other aspects of the course. Again, this is something to be monitored with a larger sample.

Table 11: Responses to class time questions

\begin{tabular}{|l|c|c|}
\hline Class time & Mean & $\begin{array}{c}\text { \% agree or } \\
\text { strongly agree }\end{array}$ \\
\hline I wish we had spent more time using Socrative & 4.29 & 86 \\
\hline Time spent on Socrative was time well spent & 4.29 & 86 \\
\hline
\end{tabular}

Noel et al. (2015) asked their students if conducting real-time polling during class was a waste of class time. The mean result suggested that responses were between 'disagree' and 'strongly disagree'. Our question was phrased in the opposite manner, but with similar results (Table 11). All but one student indicating that they wished we had spent more time using Socrative.

Table 12: Responses to privacy questions

\begin{tabular}{|l|c|c|}
\hline Privacy & Mean & $\begin{array}{c}\text { \% agree or } \\
\text { strongly agree }\end{array}$ \\
\hline $\begin{array}{l}\text { When I used Socrative I was not concerned that someone near me } \\
\text { would see how I answered }\end{array}$ & 3.86 & 86 \\
\hline $\begin{array}{l}\text { When I used Socrative I was not concerned about other students } \\
\text { seeing how I answered }\end{array}$ & 4.00 & 86 \\
\hline
\end{tabular}

Noel et al. (2015) asked if students liked that their polling results were anonymous. The mean result suggested that responses were between 'agree' and 'strongly agree'. They also asked a differently phrased question, if students felt that respondents should be identified while answering questions using real-time polling so that each person was accountable. The mean result suggested that responses were closest to 'disagree'. This suggested that the students in that study preferred anonymity. In our study (Table 12), students indicated that they were generally not concerned that someone near them would see how they answered, nor were they worried that other students would see how they answered. However, a different student did express some concern by disagreeing with the first question, with another being ambivalent in the other question. Whilst not in the majority, any student concerns along these lines need to be considered seriously.

A matter worthy of consideration is whether the use of ARS prompts students who would otherwise not participate in class discussions to become involved as a result of use of the technology. It is not possible to determine whether this occurred, but would be a consideration in future studies.

Table 13: Responses to attention questions

\begin{tabular}{|l|c|c|}
\hline Attention & Mean & $\begin{array}{c}\text { \% agree or } \\
\text { strongly agree }\end{array}$ \\
\hline $\begin{array}{l}\text { Using Socrative made me more attentive during lecture or other class } \\
\text { activities }\end{array}$ & 3.86 & 71 \\
\hline Using Socrative helped me to focus on the subject matter during class & 3.86 & 86 \\
\hline
\end{tabular}

Jain and Farley (2012) asked if ARS questions encouraged students to be more engaged in the lecture process. $69 \%$ agreed or strongly agreed that this was the case. Noel et al. (2015) asked if 
students became more attentive when their instructor directed them to respond using real-time polling. The mean result suggested that responses were closest to 'agree' (Noel et al. 2015).

Again, most of the students suggested that Socrative helped them to be more attentive, but as with the other studies it was not a strong finding.

To try to extract some further information from students about their use of Socrative, we asked three further open-ended questions. This also enabled us to trial the open-ended question feature of Socrative.

\section{Please briefly indicate what you believe were the main BENEFITS associated with using Socra-} tive

Six of the students responded to this question. The main benefits related to the level of participation and discussion that occurred after each poll, such as "You get to discuss the answers and questions \& it helps in classification of subject matter". Even the student who had difficulties with connecting noted that "Class participation has been increased but due to connectivity issues I found Socrative was time consuming".

Please briefly indicate what you believe were the main PROBLEMS associated with using Socrative

All of the seven students responded to this question. Only two, however, mentioned that they had no problems. Of the other five, each had encountered a network or connectivity issue at least once during the semester. Sometimes these related to not being able to log on at all and others related to how long it took to log on. Only one student (previously mentioned) found this to be an ongoing issue, but it is certainly something that needs to be considered.

Do you have any suggestions for how we might use Socrative more effectively?

There were five responses to this question. We were quite surprised (especially given the responses to the previous question) when all of the five responses suggested that it should be used more in the class and even in other units. For instance:

- It would benefit students and make it fun by increasing the use in the class

- Use this in other core units and electives as well, wonderful tool.

As mentioned earlier, whilst we had felt that the use of Socrative went well, we had no feedback from the students during the semester about how they appreciated its use. Again, we need to emphasise that this is only a small sample, but if the connectivity and privacy issues can be overcome then we will look to increase its use.

\section{Practical Implications}

From a local perspective, taking a holistic viewpoint of the introduction of the ARS according to the BLA framework allowed us to consider some of the issues that we may not have if we had just 'trialled' the technology will little prior thought. Certainly, considering the readiness of institution, lecturers, and students made us aware of many of the issues that we encountered, such as when students did not have access to the technology at certain times or when there were technical difficulties. The preliminary results suggest that we should spend even more time with the students at the start of the semester to make them familiar with the ARS system. Socrative has an 'app' that can be downloaded onto smartphones and tablets to simplify access to its features, so we will consider assisting students to download this in early classes. Another consideration might be to have inexpensive tablets on standby for when students encounter isolated connection issues or have forgotten to bring their own mobile devices. From an intensity of adoption viewpoint, we do not believe that we will change the nature of the use of Socrative. That is predominantly the use of multiple choice questions that lead to further discussion of student responses related to im- 
portant issues in the unit (as per Fong, 2015). We will consider introducing further question types, including those that may relate to prior reading which we intend to introduce to increase student preparation for the class. From an impact viewpoint we look forward to conducting the formal assessment of the use of Socrative in class with a larger sample of students in forthcoming semesters.

From an external viewpoint, we certainly believe that Socrative is a promising tool that adds to those existing in the ARS area. Provided the reasons for its adoption match the benefits that the technology can provide, and its limitations are understood and dealt with, we see no reason for the benefits that we have identified in our study not to be replicated elsewhere. We look forward to seeing the results of other educators incorporating its use in their curriculum.

\section{Conclusion}

In this article we have discussed the implementation of an audience response system, Socrative, by considering it as part of a blended learning environment, using Wong et al.'s (2014) BLA framework to guide the implementation. This article has outlined the early stages of a multisemester case study designed to incorporated Socrative into a Masters level unit. Many of the ARS connection and privacy issues faced by students were anticipated by the authors due to the use of the framework to assist implementation and a review of the ARS literature. The preliminary results suggest consistency with other ARS studies, but also hint at future benefits from continued use of the technology as the authors gradually move the unit from instructional delivery to a more constructivist approach.

\section{References}

Babu, S. (2007). Professional ethics and human values. New Delhi, India: Laxmi Publications.

Banks, D. (2003). Using keypad-based group process support systems to facilitate student reflection. Interact, Integrate, Impact: Proceedings of the 20th ASCILITE Conference, Adelaide.

Banks, D., \& Monday, A. (2006). Audience response systems in practice: Improving Hong Kong students' understanding of decision support systems. Australian Society for Computers in Learning in Tertiary Education Annual Conference, Sydney, Australia.

Banks, D., Monday, A., Burgess, S., \& Sellitto, C. (2010). Focusing on SMTEs: Using audience response technology to refine a research project. Issues in Informing Science and Information Technology, (7), 311-319.

Biggs, J., \& Tang, C. (2011). Teaching for quality learning at university (4th ed.). Berkshire, England.: Open University Press, McGraw-Hill International.

Bingimlas, K.A. (2009). Barriers to the successful integration of ICT in teaching and learning environments: A review of the literature. Eurasia Journal of Mathematics, 5(3), 235-245.

Blasco-Arcas, L., Buil, I., Hernández-Ortega, B., \& Sese, F. J. (2013). Using clickers in class. The role of interactivity, active collaborative learning and engagement in learning performance. Computers \& Education, 62, 102-110.

Bliuc, A., Goodyear, P., \& Ellis, R. A. (2007). Research focus and methodological choices in studies into students' experiences of blended learning in higher education. The Internet and Higher Education, $10(4), 231-244$.

Bound, H. (2011). Vocational education and training teacher professional development: Tensions and context. Studies in Continuing Education, 33(2), 107-119.

Bruce, J. (2012). Discipline specific e-training for trades tutors. Waikato, New Zealand: Ako Aotearoa. 
Chartered Quality Institute. (2015). The role and purpose of professional bodies. Retrieved from http://www.thecqi.org/Knowledge-Hub/Knowledge-portal/Compliance-and-organisations/Specialistprofessional-bodies/

Draper, S., Cargill, J., \& Cutts, Q. (2002). Electronically enhanced classroom interaction. Australian Journal of Educational Technology, 18(1), 13-23.

Easton, C. (2012). Employing a classroom response system to teach law: A case study. European Journal for Law and Technology, 3(1).

Elliott, R., \& Clayton, J. (2007). E-learning for New Zealand industry training organisations: Analysis of benefits and barriers. ICT: Providing Choices for Learners and Learning. ASCILITE Proceedings, Singapore, 10(10), 08.

Fong, M. (2015). Using technology to support discussions on sensitive topics in the study of business ethics. Journal of Information Technology Education: Research, 14, 243-256. Retrieved from http://www.informingscience.org/Publications/2268

Jain, A., \& Farley, A. (2012). Mobile phone-based audience response system and student engagement in Large-Group teaching. Economic Papers: A Journal of Applied Economics and Policy, 31(4), 428-439.

Jones, N., Chew, E., Jones, C., \& Lau, A. (2009). Over the worst or at the eye of the storm? Education Training, 51(1), 6-22.

MacGeorge, E., Homan, S., Dunning, J., Elmore, D., Bodie, G., Evans, E., Khichadia, S., Lichti, S., Feng, B., \& Geddes, B. (2008). Student evaluation of audience response technology in large lecture classes. Educational Technology Research and Development, 56, 125-145.

Machado, C. (2007). Developing an e-readiness model for higher education institutions: Results of a focus group study. British Journal of Educational Technology, 38(1), 72-82.

Mareno, C., Bremner, M., \& Emerson, C. (2010). The use of audience response systems in nursing education: Best practice guidelines. International Journal of Nursing Education Scholarship, 7(1).

Nielsen, K. L., Hansen, G., \& Stav, J. B. (2013). Teaching with student response systems (SRS): Teachercentric aspects that can negatively affect students' experience of using SRS. Research in Learning Technology, 21, Retrieved from http://www.researchinlearningtechnology.net/index.php/rlt/article/view/18989/html

Noel, D., Stover, S., \& McNutt, M. (2015). Student perceptions of engagement using mobile-based polling as an audience response system: Implications for leadership studies. Journal of Leadership Education, 14(3 (Summer)), 53-69. doi:1012806/V14/I3/R4

Parker, S. (2000). A survey of small business in Colorado. Colarado, USA: Colorado Community College and Occupational Education System.

Pittaway, L., \& Thorpe, R. (2012). A framework for entrepreneurial learning: A tribute to Jason Cope. Entrepreneurship \& Regional Development, 24(9-10), 837-859.

Poulis, J., Massen, C., Robens, E., \& Gilbert, M. (1998). Physics lecturing with audience paced feedback. American Journal of Physics, 99(5), 439-441.

Professions Australia. (2015). Ethics resource centre. Retrieved from http://www.professions.com.au/ethicscodes.html

Richards, P. (2009). Using cell phones as audience response system transmitters in civil engineering classes. Proceedings of the American Society for Engineering Education, Austin, Texas.

Stav, J., Nielsen, K., Hansen-Nygard, G., \& Thorseth, T. (2010). Experiences obtained with integration of student response systems for iPod touch and iPhone into e-learning environments. Electronic Journal of E-Learning, 8(2), 179-190. 
Swanson, H., \& Piascik, M. (2014). A pilot study on the use of lecture tools to enhance the teaching of pharmacokinetics and pharmacodynamics. Journal of Medical Education and Curricular Development, 1, 23-28.

Wong, L., Tatnall, A., \& Burgess, S. (2014). A framework for investigating blended learning effectiveness. Education + Training, 56(2/3), 233-251.

Yin, R. K. (2003). Case study research: Design and methods (3rd ed.). London, UK: Sage.

\section{Appendix}

Table 14: Relationship of questions to MacGeorge et al. (2008) questions.

\begin{tabular}{|c|c|}
\hline MacGeorge et al. (2008) question & BCO6672 equivalent question \\
\hline Exam preview & $\begin{array}{l}\text { Not included - Socrative use was not meant } \\
\text { to prepare students for other assessments }\end{array}$ \\
\hline $\begin{array}{l}\text { Because of CPS, I have a better idea of what to } \\
\text { expect on exams, quizzes, or assignments. }\end{array}$ & \multirow{3}{*}{ Not used } \\
\hline $\begin{array}{l}\text { I believe that I know more about what will be } \\
\text { emphasized on exams, quizzes, or assignments } \\
\text { because of CPS. }\end{array}$ & \\
\hline $\begin{array}{l}\text { Using CPS gives me a preview of what I will } \\
\text { need to know for exams, quizzes, or assign- } \\
\text { ments. }\end{array}$ & \\
\hline Self-Appraisal & $\begin{array}{l}\text { Self-Appraisal - Not used - there were no } \\
\text { self-assessment quizzes in Socrative }\end{array}$ \\
\hline $\begin{array}{l}\text { Because of CPS it is easier for me to tell whether } \\
\text { I am mastering course material }\end{array}$ & \multirow{3}{*}{ Not used } \\
\hline $\begin{array}{l}\text { Because of CPS I am more certain about how I } \\
\text { am performing in the class }\end{array}$ & \\
\hline $\begin{array}{l}\text { Using CPS helps me more easily determine how } \\
\text { well I am doing in the class }\end{array}$ & \\
\hline Learning & Learning \\
\hline $\begin{array}{l}\text { My knowledge of course material is improved } \\
\text { by using CPS }\end{array}$ & $\begin{array}{l}\text { My knowledge of course material is improved } \\
\text { by using Socrative }\end{array}$ \\
\hline $\begin{array}{l}\text { I understand more in this class because we use } \\
\text { CPS }\end{array}$ & $\begin{array}{l}\text { I understood more in this class because we used } \\
\text { Socrative }\end{array}$ \\
\hline CPS helps me learn course material better. & $\begin{array}{l}\text { Socrative helped me to learn the course materi- } \\
\text { al better. }\end{array}$ \\
\hline Negative Grade & $\begin{array}{l}\text { No - Socrative was not used to assess stu- } \\
\text { dents }\end{array}$ \\
\hline $\begin{array}{l}\text { CPS technology is interfering with my getting a } \\
\text { good grade. }\end{array}$ & \multirow[t]{2}{*}{ Not used } \\
\hline Because we are using CPS, I expect to get a & \\
\hline
\end{tabular}


\begin{tabular}{|l|}
\hline lower grade than I would otherwise \\
\hline Using CPS is negatively impacting my grade \\
\hline
\end{tabular}

\begin{tabular}{|c|c|}
\hline Attendance & Attendance \\
\hline $\begin{array}{l}\text { Because CPS is used, I attend class more regu- } \\
\text { larly than I would otherwise. }\end{array}$ & $\begin{array}{l}\text { Because Socrative was used, I attended class } \\
\text { more regularly than I would have otherwise. }\end{array}$ \\
\hline $\begin{array}{l}\text { Using CPS increases my likelihood of attending } \\
\text { class }\end{array}$ & Not necessary due to previous question \\
\hline CPS motivates me to attend class. & Socrative motivated me to attend class. \\
\hline Fun & Fun \\
\hline Using the CPS response pad is fun & Using Socrative was fun \\
\hline $\begin{array}{l}\text { It is exciting to answer questions using CPS } \\
\text { technology }\end{array}$ & $\begin{array}{l}\text { It was exciting to answer questions using } \\
\text { Socrative }\end{array}$ \\
\hline Liking & Liking \\
\hline I enjoy using the CPS technology & I enjoyed using Socrative \\
\hline I do not like using CPS. & $\begin{array}{l}\text { No - negative question that is just the opposite } \\
\text { of the previous question }\end{array}$ \\
\hline I have had a good experience with CPS & No - virtually repeats first question \\
\hline Future Use & Future Use \\
\hline I would like to use CPS in future classes. & No - it was the last class for most students \\
\hline $\begin{array}{l}\text { I think CPS should be used in this class in future } \\
\text { semesters. }\end{array}$ & $\begin{array}{l}\text { I think that Socrative should be used in this } \\
\text { class in future semesters. }\end{array}$ \\
\hline Preparation & Preparation \\
\hline $\begin{array}{l}\text { Using CPS makes me more likely to review my } \\
\text { notes prior to class. }\end{array}$ & Not applicable in this instance \\
\hline $\begin{array}{l}\text { Using CPS encourages me to do readings prior } \\
\text { to class. }\end{array}$ & $\begin{array}{l}\text { Using Socrative encouraged me to do readings } \\
\text { prior to class. }\end{array}$ \\
\hline $\begin{array}{l}\text { Because we use CPS I prepare for class more } \\
\text { than I would otherwise. }\end{array}$ & $\begin{array}{l}\text { Because we used Socrative I prepared for class } \\
\text { more than I would otherwise. }\end{array}$ \\
\hline Motivation & Motivation \\
\hline $\begin{array}{l}\text { CPS boosts my enthusiasm for studying the ma- } \\
\text { terial we learn in this course. }\end{array}$ & $\begin{array}{l}\text { Socrative boosted my enthusiasm for studying } \\
\text { the material we learned in this course. }\end{array}$ \\
\hline $\begin{array}{l}\text { Using CPS makes me more motivated to learn in } \\
\text { this course. }\end{array}$ & $\begin{array}{l}\text { Using Socrative made me more motivated to } \\
\text { learn in this course. }\end{array}$ \\
\hline $\begin{array}{l}\text { If we didn't use CPS, I would be less interested } \\
\text { in the topics we cover in this course. }\end{array}$ & $\begin{array}{l}\text { If we didn't use Socrative, I would be less in- } \\
\text { terested in the topics we covered in this course. }\end{array}$ \\
\hline Ease of Use & Ease of Use \\
\hline
\end{tabular}




\begin{tabular}{|l|l|}
\hline Using the CPS technology is easy. & Using Socrative was easy. \\
\hline I have no problems using the CPS technology & I had no problems using Socrative \\
\hline Using the CPS technology is pretty hard & No - just the opposite of the first question \\
\hline Participation & Participation \\
\hline $\begin{array}{l}\text { I feel more engaged during class because we use } \\
\text { CPS. }\end{array}$ & $\begin{array}{l}\text { I felt more engaged during class because we } \\
\text { used Socrative }\end{array}$ \\
\hline $\begin{array}{l}\text { Because we use CPS, I have a greater sense of } \\
\text { participation in the class. }\end{array}$ & No- virtually repeats previous question \\
\hline $\begin{array}{l}\text { Using CPS heightens my interest in whatever } \\
\text { else we do during class. }\end{array}$ & $\begin{array}{l}\text { Using Socrative heightened my interest in } \\
\text { whatever else we did during class. }\end{array}$ \\
\hline Class Time & Class Time \\
\hline I wish we spent less time using CPS. [Reverse] & I wish we had spent more time using Socrative \\
\hline Time spent on CPS is time well spent. & Time spent on Socrative was time well spent. \\
\hline Privacy & Privacy \\
\hline $\begin{array}{l}\text { I have thought about not answering or actually } \\
\text { did not answer a CPS question because I was } \\
\text { afraid someone near me would see how I an- } \\
\text { swered. [Reverse] }\end{array}$ & $\begin{array}{l}\text { When I used Socrative I was not concerned that } \\
\text { someone near me would see how I answered }\end{array}$ \\
\hline $\begin{array}{l}\text { As I use the CPS keypad, I am concerned about } \\
\text { other students seeing how I answer. [Reverse] }\end{array}$ & $\begin{array}{l}\text { When I used Socrative I was not concerned } \\
\text { about other students seeing how I answered }\end{array}$ \\
\hline Attention & Attention \\
\hline $\begin{array}{l}\text { Using CPS makes me more attentive during lec- } \\
\text { ture or other class activities. }\end{array}$ & $\begin{array}{l}\text { Using Socrative made me more attentive during } \\
\text { lecture or other class activities. }\end{array}$ \\
\hline $\begin{array}{l}\text { Using CPS helps me focus on the subject matter } \\
\text { during class. }\end{array}$ & $\begin{array}{l}\text { Using Socrative helped me to focus on the sub- } \\
\text { ject matter during class. }\end{array}$ \\
\hline
\end{tabular}

\section{Biographies}

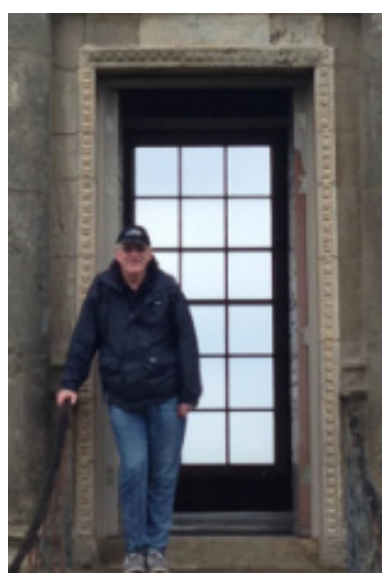

Stephen Burgess is an Associate Professor in Information Systems in the College of Business. He has research and teaching interests that include the use of ICTs in small businesses (particularly in the tourism field), the websites of community based organisations, the use of usergenerated content in tourism and $\mathrm{B} 2 \mathrm{C}$ electronic commerce. He has received a number of competitive research grants in these areas. Stephen has completed several studies related to website features in small businesses and how well websites function over time. 


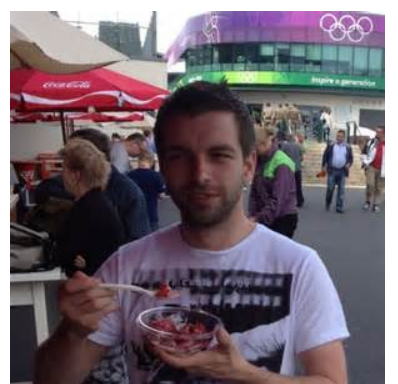

Scott Bingley is a lecturer in Information Systems in the College of Business at Victoria University. He has research and teaching interests that include the use of ICTs and Internet adoption in sporting organisations, and technology use in small business. His PhD investigated the level that Internet applications being adopted within local sporting clubs. This involved an investigation of the factors that affected adoption, based on Rogers' Innovation-Decision Model (2003), on both local sporting clubs and their members.

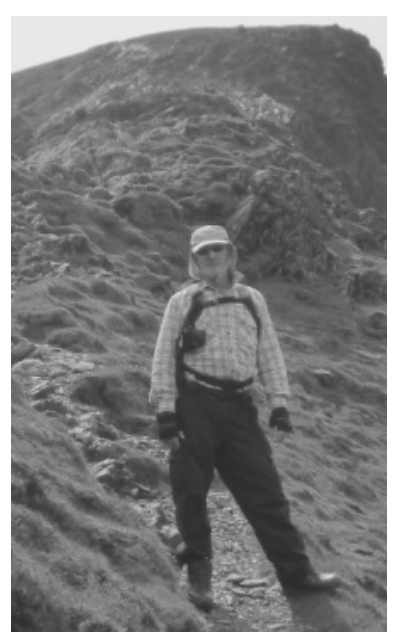

David A Banks is an Adjunct Fellow in the College of Business at Victoria University. He is based in the UK and his research interests include teaching and learning in higher education, ethical issues in the use of group support tools and processes, information systems development methodologies and audience response technologies. He is a member of the British Computer Society and holds Chartered IT Professional status. 